\title{
Die Commerzbank und die Juden 1933-1945, red. Ludolf Herbst, Thomas Weihe, C.H. Beck, München 2004
}

Recenzowana praca zbiorowa stanowi uzupełnienie badań dotyczących uwikłania największych prywatnych banków w Niemczech w proces wywłaszczenia, a następnie wyniszczenia europejskich Żydów. Prezentuje ona wyniki badań zespołu naukowców pod kierunkiem prof. Ludolfa Herbsta z Uniwersytetu Humboldta w Berlinie w ramach szerszego projektu dotyczącego historii Commerzbanku (za lata 1870-1958), który został zainicjowany w 1999 r. przez sam bank. Sama data początku projektu nie jest chyba przypadkowa - właśnie wtedy przetoczyła się tam debata na temat udziału niemieckich banków prywatnych w finansowaniu Holokaustu. Chociaż dotyczyła głównie odpowiedzialności Deutsche Bank i Dresdner Bank, nie mogła jednak ominąć trzeciego dużego banku prywatnego. Commerzbank w czasach reżimu nazistowskiego niewątpliwie ustępował dwóm pozostałym zarówno wielkością, jak i pozycją rynkową. Nie musiało to jednak z góry oznaczać, że jego rola w procesie „aryzacji” gospodarki była przez to mniejsza. Często przecież mniejsi gracze rynkowi są w stanie szybciej zareagować na „nowe możliwości” ekspansji biznesowej. Proces „aryzacji” niewątpliwie był taką „szansą rynkową”, na której bank potencjalnie mógł skorzystać, oferując pośrednictwo i pomoc finansową w przejmowaniu czy zawłaszczaniu żydowskiego mienia.

Wyniki przeprowadzonych analiz potwierdzają jednak, że Commerzbank z pewnością nie należał do liderów tego procesu. Wszystkich autorów publikacji nurtuje wszak pytanie, czy był to efekt świadomego zdystansowania się banku od oficjalnej polityki rządu z pobudek moralnych, czy też strategicznych, opartych na uwzględnieniu prawdopodobieństwa przyszłej klęski Niemiec i ewentualnych represji, które mogłyby w przyszłości zaszkodzić instytucji uwikłanej w prześladowanie Żydów. Postawienie takiego problemu badawczego jest uzasadnione, gdyż po zakończeniu wojny Commerzbank uchodził w powszechnym mniemaniu za bank, który dystansował się od działań „aryzacyjnych” i nie był zamieszany w żaden spektakularny przypadek. Za tą hipotezą mogłyby przemawiać konkretne sytuacje przedstawione w studium dotyczącym usunięcia żydowskich pracowników banku (autorstwa Thomasa Weihe) i w kolejnym, na temat uczestnictwa w wywłaszczeniach żydowskich przedsiębiorstw w Niemczech przed 1938 r. (autorstwa Ludolfa Herbsta). Oficjalna dokumentacja banku zawiera korespondencję (zazwyczaj między centralą a filią banku) świadczącą o silnym oporze dyrektorów lokalnych oddziałów przed zwolnieniami niektórych pracowników. Choć stosowano przy tym antysemicką argumentację, dowodząc, że zatrzymanie żydowskiego pracownika zatrzyma także żydowską klientelę, to wiele wskazuje na to, że chodziło raczej o względy humanitarne, tj. o pomoc wieloletniemu współpracownikowi, który znalazł się w po- 
trzebie. Choć klienci żydowscy stanowili w niektórych oddziałach istotny procent (w analizowanej filii w Mainz należało do nich ok. 17\% depozytów), to przecież pozostawienie konkretnej osoby na stanowisku nie mogło wpłynąć znacząco ani na wyniki oddziału, ani tym bardziej całego banku. Autor analizuje także przypadek odwrotny, gdy zwolniono dyrektora oddziału w Monachium, argumentując, że jego obecność uniemożliwia zbudowania relacji biznesowych z lokalnymi władzami NSDAP. W kolejnych latach po zmianie kadrowej oddział ten raportował spektakularny wzrost zysków, który w żaden sposób nie mógł wynikać jedynie z obracania partyjnymi pieniędzmi. Najprawdopodobniej zwolniony menedżer obiektywnie źle wykonywał swoją pracę (wspomina o tym zresztą cytowana relacja powojenna) i to zastąpienie go kim innym przyniosło taką poprawę wyników oddziału. Ciekawe jednak jest to, że oficjalna dokumentacja towarzysząca tej sprawie nie odwołuje się do argumentacji merytorycznej, ale antysemickiej. Oznacza to, że używając jej, można było liczyć w banku na szybsze załatwienie sprawy, aniżeli dyskutując o kompetencjach menedżera. Ta okoliczność kładzie pierwszy cień na potoczne wyobrażenie o zdystansowaniu się banku od antysemickiej nagonki.

Do interesujących wniosków doszedł Ludolf Herbst, który analizował relacje banku z przedsiębiorstwami należącymi do Żydów przed wybuchem II wojny światowej. Z jego badań wynika, że takie przedsiębiorstwa nadal były pożądanymi klientami banku, choć narastające restrykcje reżimu podnosiły ich ryzyko kredytowe. Bank miał świadomość, że firmy te są narażone na wykluczenie z kontraktów publicznych czy inne represyjne działania administracyjne. Wiązało się z tym ryzyko utraty części dochodów, co musiało negatywnie się odbić na ocenie ich zdolności do obsługi zadłużenia. Charakterystyczna jest korespondencja między centralą a oddziałem w Cottbus na temat firmy Gustav Samson. Była ona jeszcze w 1936 i 1937 r. lokowana przez bank w najniższej klasie ryzyka kredytowego i dlatego bank finansował ją w oparciu o niezabezpieczone linie kredytowe, zmierzając do osiągnięcia pozycji głównego banku tego klienta. Od pewnego momentu centrala zaczyna jednak stawiać nowe warunki - domaga się zabezpieczenia kredytu oraz regularnego dostarczania bilansu i rachunku wyników. Oddział wzbraniał się przed ich wypełnieniem, twierdząc, że „jest bardzo zadowolony z posiadania tak doskonałego klienta”, a eskalacja żądań może doprowadzić do irytacji właściciela. Trzeba jednak zaznaczyć, że postulaty centrali nie były szczególnie uciążliwe, jeśli porównamy je z obecnymi realiami transakcji kredytowych, gdzie zabezpieczenia rzeczowe oraz obowiązek dostarczania sprawozdań finansowych należą do standardowych warunków kredytowania. Ten przypadek pokazuje również, że bank bynajmniej nie wykazał się nadmierną gorliwością we wprowadzaniu ograniczeń dla przedsiębiorstw żydowskich. Firma Gustav Samson zabezpieczyła kredyt wpisem hipotecznym w 1938 r., czyli mniej więcej w tym samym czasie, kiedy zaczęły obowiązywać przepisy prawne nakładające na banki obowiązek żądania zabezpieczeń rzeczowych wobec klientów „niearyjskich”.

Publikacja przynosi natomiast dowody uwikłania banku w transakcje związane z procesem przejmowania własności firm żydowskich, w którym Commerzbank 
pełnił rolę pośrednika, finansisty i doradcy. Ciekawe jest jednak to, że inicjatywa wychodziła nieraz od żydowskich przedsiębiorców, którzy widząc narastającą falę antysemityzmu, sami próbowali chronić przedsiębiorstwa i swój majątek. Do 1938 r. sprzedaż udziałów w zasadzie nie była kontrolowania przez władze i dlatego mogła się odbywać na zasadach rynkowych w oparciu o negocjacje swobodnie działających stron. Jeśli żydowski przedsiębiorca nie potrafił samodzielnie znaleźć zaufanego nabywcy (często bywali nimi menedżerowie jego firmy), zdarzało się, że prosił bank o pomoc w dalszych poszukiwaniach. Przedstawione materiały wskazują, że bank nie osiaggał w ten sposób nadzwyczajnych zysków. Chodziło głównie o ochronę związku z firmą jako klientem banku. Zmiana własności zawsze pociągała za sobą ryzyko utraty relacji biznesowej z przejmowanym przedsiębiorstwem. Aspekt komercyjny był dominujący, o czym świadczą przypadki odmowy udzielenia „aryzatorom” kredytu na sfinansowanie przejęcia firmy żydowskiej, gdy ocena ryzyka kredytobiorcy wypadła negatywnie.

Podsumowując wątek „aryzacyjny”, autorzy tomu wskazują na pragmatyzm biznesowy jako główny motor działania banku. Choć są bardzo oszczędni w formułowaniu jakichkolwiek usprawiedliwień, jestem skłonny uwierzyć w hipotezę, że pracownicy banku niejednokrotnie podejmowali decyzje, które były zgodne z dobrze pojętymi interesami ich wieloletnich klientów. Ale w grę wchodzą relacje biznesowe nie tylko z żydowskimi firmami, ale także z osobami fizycznymi, które występowały zazwyczaj w roli depozytariuszy. Tu obraz działalności banku jest zupełnie inny. Po 1938 r. naziści nakazali zamrożenie żydowskich kont, z których zezwalali wypłacać jedynie niewielkie sumy na pokrycie bieżących kosztów utrzymania. Z tego powodu bank został uwikłany w rolę częściowego zarządcy depozytów, co niewątpliwie generowało wysokie koszty operacyjne. Jeśli hipoteza o świadomym dystansowaniu się banku od działań antysemickich byłaby w pełni prawdziwa, to należałoby oczekiwać, że bank ten zrezygnuje z decyzji, które pogarszały i tak już fatalną sytuację klientów. Commerzbank narzucił jednak swoim żydowskim klientom bardzo wysokie opłaty na pokrycie kosztów operacyjnych i nie akceptował przy tym żadnych odwołań. A przecież te koszty w żaden sposób nie mogły zachwiać wynikami finansowymi banku. W 1943 r. weszło w życie zarządzenie o konfiskacie depozytów Żydów niemieckich, zarówno tych, którzy wyemigrowali, jak i deportowanych na Wschód. Commerzbank, podobnie jak inne banki, odniósł się do tego zarządzenia z pewną rezerwą. Wszystko wskazuje na to, że nie było tu żadnego podtekstu moralnego, a jedynie kwestia braku precyzji przepisów, które chroniłyby bank przed ewentualnymi roszczeniami z zagranicy tych osób, które np. miały żydowsko brzmiące nazwiska, ale nie podpadały pod nowe przepisy.

Prawdopodobna wydaje się więc hipoteza, która wskazuje zupełnie inne powody niewielkiego zaangażowania banku w działania uderzające w klientelę żydowską. Według tej hipotezy pozycja rynkowa Commerzbanku w konkurencji o biznes „aryzacyjny” była zbyt słaba w starciu z Dresdner Bank i Deutsche Bank z jednej strony oraz z publicznymi kasami oszczędnościowymi z drugiej. Był to bowiem tradycyjny bank średniej przedsiębiorczości (tzw. Mittelstand). W relacjach z najwięk- 
szymi firmami i koncernami liczyli się tylko dwaj wielcy konkurenci. Commerzbank mógłby mieć sukcesy w spektakularnych przypadkach „aryzacji” najbardziej znaczących przedsiębiorstw, gdyby konkurenci zachowali w tym względzie pewną wstrzemięźliwość. W praktyce tak jednak nie było, choć badacze podkreślają różnicę pomiędzy gorliwością menedżerów Dresdner Bank a powściągliwością Deutsche Bank, przynajmniej przed 1938 r. i na terenie starej Rzeszy (tzn. w granicach z 1937 r.). Z drugiej strony Commerzbank nie angażował się w likwidacje małych żydowskich firm, ponieważ była to klientela publicznych kas oszczędnościowych, nad którymi nadzór i zarząd zawsze należał do lokalnych nazistowskich urzędników.

Brak „sukcesów aryzacyjnych” mógł być też konsekwencją przyjęcia wadliwego modelu ekspansji w krajach okupowanych. Bardzo dobrym przykładem jest tu działalność Commerzbanku na terenie Protektoratu Czech i Moraw (artykuł autorstwa duetu Christoph Kreutzmüller i Jaroslav Kučera), gdzie początkowo zrezygnował on z przejęcia dużej lokalnej instytucji kredytowej, koncentrując się na tworzeniu od podstaw własnej placówki. W praktyce oznaczało to zepchnięcie banku do drugiej ligi. Musiało to zostać dostrzeżone po pewnym czasie, ponieważ dokumentacja źródłowa zawiera informacje o staraniach przejęcia niewielkiego banku czeskiego Hašek \& Co., do czego ostatecznie doszło w 1944 r. Mamy więc tutaj do czynienia z oczywistą strategią ekspansji, tyle tylko, że źle zaprojektowaną.

Osobną kwestię stanowi sprawa bezpośredniego uwikłania banku w Holokaust. $Z$ jednej strony chodzi o zbadanie finansowania przedsięwzięć gospodarczych towarzyszących represjom i wymordowaniu Żydów na Wschodzie, z drugiej o próbę ustalenia, co bank i jego pracownicy mogli wiedzieć o losie, jaki zgotowano Żydom.

Rezultaty badań przeprowadzonych przez Ingo Loose wskazują, że Commerzbank nie finansował bezpośrednio KL Auschwitz czy innych obozów zagłady. Okazuje się jednak, że współfinansował firmę J. A. Topf \& Söhne z Erfurtu, która budowała krematoria w Brzezince. $\mathrm{W}$ dokumentacji banku odnaleziono informacje, że przedsiębiorstwu udzielono kredytów na działalność bieżącą, a ich zabezpieczenie stanowiła cesja należności z realizowanych kontraktów. W jednym z zestawień znajduje się faktura - na niewielką kwotę 1000 RM - stanowiąca płatność z KL Auschwitz. Narzuca się pytanie, czy bank mógł wiedzieć, jaki był charakter realizowanych kontraktów. Zachowana dokumentacja na to nie wskazuje. Zazwyczaj rozmowa doradcy bankowego z klientem dotyczy tylko jego kluczowych relacji biznesowych. Firma Topf \& Söhne realizowała większość swoich obrotów przy budowie elewatorów i suszarni zbożowych. Budowa krematoriów przynosiła niewielką część przychodów firmy, które głównie wiązały się z obiektami cywilnymi. Ewentualne badanie należności handlowych skupia się w banku tylko na ich aspekcie prawnym (ważność cesji i fakt jej przyjęcia do wiadomości przez dłużnika).

Nie znaczy to jednak, że pracownicy banku nie stykali się w codziennej pracy z problemem wysiedlania i prześladowania Żydów. Commerzbank uczestniczył $\mathrm{w}$ udzieleniu zarządowi getta $\mathrm{w}$ Łodzi kredytu konsorcjalnego, poręczonego przez rząd Rzeszy. W takim układzie bank był zobowiązany uczestniczyć w transakcji. Dokumentacja nie mówi jednak nic o tym, czy uczestnictwo w kredycie wynikało 
z inicjatywy samego banku, czy też było konsekwencją „zaproszenia” wystosowanego przez czynniki administracyjne. Praca opisuje również przypadki finansowania firm niemieckich korzystających z przymusowej pracy Żydów. Są też przypadki konfiskowania zamrożonych depozytów Żydów niemieckich deportowanych na wschód.

Lektura opracowania nie potwierdza więc potocznej opinii o Commerzbanku jako instytucji, która celowo unikała udziału w prześladowaniach Żydów. Na pierwszy rzut oka decyzje banku rządziły się logiką działalności biznesowej, w której mieści się ekspansja na nowe rynki, mitygowanie ryzyka kredytowego czy działania w kierunku bezwzględnego pokrycia kosztów operacyjnych. Wyniki badań nie wskazują jednak na żaden ślad rozważań strategicznych, które uwzględniałyby inny scenariusz dalszego rozwoju wydarzeń niż ostateczne zwycięstwo Wielkiej Rzeszy. Być może rację ma Harold James, który analizując historię Deutsche Bank, twierdzi, że po wybuchu wojny nie było mowy o jakiejkolwiek spójnej strategii, natomiast działania gospodarcze o charakterze „aryzacyjnym” były efektem inicjatywy młodych menedżerów szukających w takich „wyzwaniach” możliwości przyspieszenia kariery. Nie stanowi to jednak usprawiedliwienia dla żadnego banku, także dla Commerzbanku, który na tym polu wykazał się po prostu mniejszą skutecznością od innych. 